\title{
NEW INSIGHTS ON SOME 6-CHLORO-9H-CARBAZOL DERIVATIVES CONCERNING THEIR IN VITRO ANTIOXIDANT CAPACITY AND IN VIVO CYTOTOXICITY
}

\author{
ALEXANDRA TEODORA BORDEI (TELEHOIU) ${ }^{1}$, TEODORA COSTEA ${ }^{1} *{ }^{*}$, CARMEN LIMBAN $^{1}$, \\ DIANA CAMELIA NUȚA ${ }^{1}$, CERASELA ELENA GIRD ${ }^{1}$, IRINA ZARAFU ${ }^{2}$, TEODORA DALILA \\ BALACI ${ }^{1}$, OANA KARAMPELAS ${ }^{1}$, ROBERT VIOREL ANCUCEANU ${ }^{1}$ \\ I "Carol Davila” University of Medicine and Pharmacy, Faculty of Pharmacy, 6 Traian Vuia Street, 020956, Bucharest, \\ Romania \\ ${ }^{2}$ University of Bucharest, Faculty of Chemistry, 4-12 Regina Elisabeta Boulevard, 030018 Bucharest, Romania
}

*corresponding author: teodora.costea@umfcd.ro

Manuscript received: December 2020

\begin{abstract}
According to recent research, both carbazol and 1,3,4-oxadiazol derivatives are known for their antioxidant properties. The aim of our research was the evaluation of antioxidant activity and in vivo cytotoxicity of some new heterocyclic compounds, which both contain pharmacophore groups. The antioxidant activity was evaluated by means of scavenger activity towards 2,2'-diphenyl-1-picrylhydrazyl (DPPH) and 2,2'-azino-bis(3-ethylbenzothiazoline-6-sulphonic acid) (ABTS ${ }^{\circ+}$ ) free radicals. In vivo cytotoxicity was assessed using Artemia franciscana nauplii lethality bioassay. Our results have shown that the analysed compounds can be further used for their antioxidant capacity. For the analysed concentration interval (25 - 1000 $\mu \mathrm{M})$, the scavenger capacity towards $\mathrm{ABTS}^{\cdot+}$ free radical was higher compared to the DPPH assay. All tested compounds showed an adequate safety profile. Further research is needed for evaluation of in vivo antioxidant effects of tested compounds and furthermore their safety via pre-clinical tests.
\end{abstract}

\section{Rezumat}

Cercetări recente au arătat că atât derivații carbazolului, cât și cei ai 1,3,4-oxadiazolului prezintă proprietăţi antioxidante. Scopul acestui studiu a constat în evaluarea activității antioxidante și a citotoxicității unor noi molecule, care conțin ambele grupări farmacofore. Activitatea antioxidantă a fost determinată pe baza capacității de chelatare a radicalilor liberi 2,2'difenil-1-picrilhidrazil (DPPH) și 2,2'-azino-bis (acid 3-etilbenzotiazolin-6-sulfonic) (ABTS ${ }^{*+}$ ). Citotoxicitatea noilor compuși a fost analizată folosind specia marină Artemia franciscana. Rezultatele obținute au arătat că derivații analizați prezintă activitate antioxidantă, indiferent de natura radicalului liber, totuşi capacitatea de scavenger a radicalului $\mathrm{ABTS}^{\circ+}$ pe domeniul de concentrații folosit $(25-1000 \mu \mathrm{M})$ a fost superioară valorilor obținute prin metoda DPPH. În ceea ce privește citotoxicitatea, majoritatea compușilor sunt lipsiți de toxicitate sau toxicitatea este extrem de redusă, ceea ce denotă un profil de siguranță ridicat. Sunt necesare cercetări viitoare privind potențialul antioxidant al noilor compuși, prin teste in vivo, precum și evaluarea profilului de siguranță în studii pe animale de laborator.

Keywords: carbazol derivatives, 1,3,4-oxadiazol derivatives, antioxidant activity, cytotoxic activity

\section{Introduction}

The importance of heterocycles in drug discovery is one of the major areas in medicinal chemistry [2]. The development of heterocyclic compounds with potential antioxidant activity have recently incited the interest of scientists [2]. It is well known that antioxidants, both natural and synthetic, play an important role in many fields. They are used for preserving the quality of foods (antioxidants prevent oxidative deterioration of fats), in the pharmaceutical industry and for maintaining human health being [26]. It is well known that oxidative stress is involved in aging and the development of several diseases (cancer, diabetes, cardiovascular disease, Alzheimers's etc.) [26]. Antioxidants neutralize free radicals and prevent oxidation of a substrate by various mechanisms: (i) chain breakers, (ii) free radical interceptors, (iii) oxygen scavengers, (iv) metal chelating, (v) decomposition to non-radical species or (vi) absorption of UV radiation [26].

The carbazol nucleus is an important aromatic heterocycle, with a tricyclic structure, containing two benzene rings on other side, and a five-member nitrogen containing ring in the middle [2, 14]. Carbazol and its derivatives are an important class of nitrogen containing heterocyclic compounds, which are widely spread in nature. The carbazol ring is present in a variety of naturally occurring medicinally compounds (such as murrayafoline or carbazomycins) [14]. Series of carbazol derivatives are known for a wide range of pharmacological activities such as antioxidant, anti- 
inflammatory, antibacterial or antitumor properties $[2,3,14]$. Recent research has also shown potential antioxidant effects for several 1,3,4-oxadiazol derivatives [3]. Thus, joining these two pharmacophoric fragments in the same molecule may enhance the antioxidant potential.

Taking into consideration the scientific data, the aim of our paper was the evaluation of in vitro antioxidant capacity (by means of scavenger activity towards DPPH and $\mathrm{ABTS}^{\circ+}$ free radicals) and in vivo cytotoxicity (using Artemia franciscana nauplii lethality bioassay) of some new 6-chloro-9H-carbazol derivatives.

\section{Materials and Methods}

Tested compounds

The tested compounds (Figure 1) were three N[(2RS)-2-(6-chloro-9H-carbazol-2-yl)propanoyl]-

N'-R-substituted-benzoilhydrazine (1a-c) and their cyclized (RS)-1-(6-chloro-9H-carbazol-2-yl)-1(1,3,4-oxadiazol-2-yl) ethane derivatives (2a-c).

The synthesis and physico-chemical properties of these derivatives, along with other biological effects were previously reported [4].

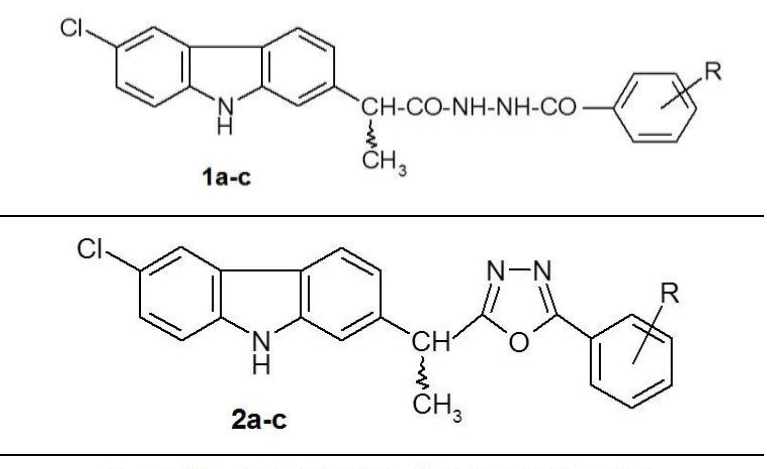

$\mathrm{R}=-\mathrm{H}(\mathbf{1} \mathrm{a}, \mathbf{2 a}), 4-\mathrm{Cl}(\mathbf{1} \mathbf{b}, \mathbf{2 b}), 3-\mathrm{CF}_{3}(\mathbf{1 c}, \mathbf{2 c})$

Figure 1.

The chemical structure of N-[(2RS)-2-(6-chloro-9H-carbazol-2-yl)propanoyl]-N'-R-substituted-benzoilhydrazine (1a-c) and their cyclized $(R S)-1-(6-c h l o r o-9 H$-carbazol-2-yl)-1-(1,3,4-oxadiazol-2-yl)ethane derivatives (2a-c)

\section{Reagents and solvents}

DPPH (Sigma-Aldrich, Germany), ascorbic acid (Roth, Germany), 2,2'-azinobis-(3-ethylbenzothiazoline-6sulfonic acid) diammonium salt (Sigma-Aldrich, Germany), potassium persulfate (Merck, Germany), ethanol, dimethylsulfoxide (DMSO).

Antioxidant activity

Preparation of samples for antioxidant activity evaluation: the analysed compounds (1a-c and 2a-c) were dissolved in a mixture of $96 \%$ ethanol:DMSO = 99:1 (v/v). The concentration of each stock solution was $1000 \mu \mathrm{M}$. Successive dilutions were made in order to obtain different concentrations: $25 \mu \mathrm{M}, 50$ $\mu \mathrm{M}, 75 \mu \mathrm{M}, 100 \mu \mathrm{M}, 250 \mu \mathrm{M}$ and $500 \mu \mathrm{M}$.

Scavenger activity towards DPPH (2,2-diphenyl-1picrylhydrazyl) free radical

The antioxidant activity was determined according to Ohnishi M et al. [12, 22].

Up to now, scientific literature has not provided a standard work procedure, therefore one can find multiple variants of the assay. For our determination, in order to render soluble the DPPH free radical, we have chosen ethanol as a solvent, although according to the scientific literature hydroethanolic mixtures (above $50 \%$ ) or methanol can be used [27]. Ethanol was chosen, based on the tested compounds solubility (see preparation of samples). According to the scientific literature, the reaction time between the free radical and the sample varies between $5 \mathrm{~min}$. [28], $15 \mathrm{~min}$. [30], $30 \mathrm{~min}$. [5], $90 \mathrm{~min}$. [17] or until a plateau is reached [21]. For our analyses we have used a 30 min. reaction time, which was frequently used in our previous studies [8, 9].

Briefly, $0.5 \mathrm{~mL}$ of $25-1000 \mu \mathrm{M}$ tested solutions was mixed with $3 \mathrm{~mL}$ DPPH ethanolic solution $(0.1$ $\mathrm{mM})$. The mixture was incubated in the darkness, at room temperature for $30 \mathrm{~min}$. [9]. The absorbance was measured at $\lambda=515 \mathrm{~nm}$ (Jasco V-530 spectrophotometer, Jasco, Japan) [20] against ethanol, that was used as a blank.

The DPPH free radical scavenger activity (I\%) was determined according to the following formula [5]:

$$
I \%=\frac{A_{\text {Control }}-A_{\text {sample }}}{A_{\text {Control }}} \times 100,
$$

where: $\mathrm{A}_{\text {control }}=$ absorbance of the $0.1 \mathrm{mM} \mathrm{DPPH}$ solution in the absence of the tested compounds $(1.000 \pm 0.02), \mathrm{A}_{\text {sample }}=$ absorbance of the $0.1 \mathrm{mM}$ DPPH solution in the presence of tested compounds after 30 min.

The antioxidant activity was expressed as ascorbic acid equivalents (mM ascorbic acid/g substance), using a calibration curve (concentration $v s$. absorbance), obtained in the same experimental conditions (0.05 - 0.4 $\mathrm{mg} / \mathrm{mL}, \mathrm{R}^{2}=0.9975, \mathrm{n}=5$ ), as previously described [8]. Scavenger activity towards ABTS $^{++}$(2,2'-azinobis-(3ethylbenzothiazoline-6-sulfonic acid) free radical 
The antioxidant activity was performed according to Re R. and co-workers, as previously described [9, 24]. Briefly, $0.5 \mathrm{~mL}$ of $25-1000 \mu \mathrm{M}$ tested solutions was mixed with $3 \mathrm{~mL} \mathrm{ABTS}{ }^{*+}$ ethanolic solution and kept in the dark, at room temperature for $6 \mathrm{~min}$. The absorbance was measured at $\lambda=734 \mathrm{~nm}$ (Jasco V-530 spectrophotometer) towards ethanol, used as a blank [24, 29].

$\mathrm{ABTS}^{\circ+}$ free radical scavenger activity (I\%) was determined according to the following formula:

$$
I \%=\frac{A b s_{(t=0 \mathrm{~min})}-A b s_{(t=6 \mathrm{~min})}}{A b s_{(t=0 \mathrm{~min})}} \times 100,
$$

where: $\mathrm{Abs}_{\mathrm{t}}=0$ min $=\mathrm{ABTS}^{\circ+}$ solution absorbance in the absence of tested compounds $(0.700 \pm 0.02)$, $\mathrm{Abs}_{\mathrm{t}}=6$ min $=\mathrm{ABTS}^{\circ+}$ solution absorbance after 6 min. incubation with analysed compounds.

The antioxidant activity was expressed as ascorbic acid equivalents ( $\mathrm{mM}$ ascorbic acid/g substance), using a calibration curve (concentration $v s$. absorbance), obtained in the same experimental conditions (0.01-0.1 $\mathrm{mg} / \mathrm{mL}, \mathrm{R}^{2}=0.9912, \mathrm{n}=6$ ) as previously described [8]. Statistical analysis

Antioxidant assays were performed in triplicate and results are presented as mean \pm standard deviation (SD) of three independent determinations. The statistical analysis was performed using Microsoft Office ${ }^{\circledR}$ (Excell 2007) and GraphPad Prism (GraphPad Prism vers. 5 for Windows, Graph Pad, USA). The statistical significance of the difference between the analysed compounds was evaluated using one-way ANOVA followed by Tukey post-test. The correlation between the antioxidant methods was determined using Pearson coefficients. A value of $p<0.05$ was considered the threshold for a statistically significant difference.

In vivo Artemia franciscana cytotoxicity evaluation The assessment of toxicity on Artemia franciscana Kellog was carried out using the method established by Meyer BM et al. [18] and Sam TW [25], with minor adaptations suggested by more novel bibliographic sources $[1,6,7]$.

The cysts were purchased from S.K. Trading, having an origin stated as $100 \%$ from Great Salt Lake, USA. Artificial seawater obtained from a commercially available salt mixture (Coral Marine, Grotech) was used as a medium. The salts were dissolved in distilled water using an ultrasound bath for 10 minutes, at a concentration of $30 \mathrm{~g} / \mathrm{L}$, according to the guidance of the cyst provider. The hatching was carried out at an average temperature of $26^{\circ} \mathrm{C}$, using an air pump for the appropriate aeration of the medium and was initiated about 48 hours before carrying out the testing proper.

The test was performed in a 24 -well $(6 \times 4)$ plate, in triplicate (three wells for each concentration evaluated). Taking into account the limited solubility of the substances to be tested, these were suspended in artificial seawater using sodium alginate $0.045 \%$ to ensure the stability, the testing being thus made at the level of the solubility limit. For each substance, the following concentrations were used: 100, 50, 25, 12.5 and $6.2 \mu \mathrm{g} / \mathrm{mL}$. The suspensions were prepared by successive dilutions from the initial one (with a $100 \mu \mathrm{g} / \mathrm{mL}$ concentration). A sodium alginate solution in artificial seawater $(0.045 \%)$ was employed as a negative control. The hatched nauplii were separated from the cyst residues and concentrated in a well with the help of artificial light, and then transferred in wells using a micropipette. Between 10 and 15 nauplii were transferred in each well, in the testing suspensions (1.5 mL of testing suspension per well). All nauplii, dead and alive, were counted at $24 \mathrm{~h}$ after their placing into contact with the testing suspensions. The concentration-lethality relationship was modelled logistically with four parameters (4PL), using an implementation with several robust variants of parameter estimation in the R package "dr4pl" [15].

\section{Results and Discussion}

\section{Antioxidant activity}

Scavenger activity towards DPPH free radical

DPPH is a violet colour free radical which is reduced in the presence of an antioxidant to its corresponding hydrazine, which is pale yellow [11, 20]. The method was first described by Brand-Williams W et al. [5]. It is a rapid and simple method that is widely used for antioxidant capacity evaluation of different compounds. Moreover, its results are well correlated with other antioxidant assays (such as $\mathrm{ABTS}^{\circ+}$ ) $[10,16]$. The DPPH assay is mainly an electron transfer based method [11], although some authors consider that it has a mixt mechanism (both electron and hydrogen atom transfer); nevertheless, the hydrogen atom transfer is not the prevailing mechanism [23].

Results regarding the antioxidant activity are presented in Tables I and II and Figure 2. Our results pointed out, that for all analysed compounds the absorbance values (Table I) and inhibition (\%) (Figure 2), decreased and respectively increased with concentration. The inhibition varied between $9.95 \%$ (for $\mathbf{1 a}-25 \mu \mathrm{M}$ ) and 17.71\% (for $\mathbf{1 c}-1000 \mu \mathrm{M}$ ). Together with compound 1c, compound $\mathbf{1 b}$ scavenger activity was $16.19 \%$ at the highest concentration. Among the analysed compounds, the lowest free radical scavenger activity was observed for compound 1a, at all tested concentrations. Regarding ascorbic acid equivalents (Table II), the antioxidant activity increased as follows $\mathbf{1 a}<\mathbf{1 c}<$ $\mathbf{2 c}<\mathbf{2 a}$. For compounds $\mathbf{1 b}$ and $\mathbf{2 b}$ ascorbic acid equivalents were not determined, since the absorbance values were not enclosed in the calibration curve. 
Absorbance values of the DPPH solution in the presence of tested compounds

\begin{tabular}{|c|c|c|c|c|c|c|c|}
\hline \multirow{2}{*}{ Compound } & \multicolumn{9}{|c|}{ Concentration $(\boldsymbol{\mu M})$} \\
\cline { 2 - 8 } & $\mathbf{2 5} \boldsymbol{\mu M}$ & $\mathbf{5 0} \boldsymbol{\mu M}$ & $\mathbf{7 5} \boldsymbol{\mu M}$ & $\mathbf{1 0 0} \boldsymbol{\mu M}$ & $\mathbf{2 5 0} \boldsymbol{\mu M}$ & $\mathbf{5 0 0} \boldsymbol{\mu M}$ & $\mathbf{1 0 0 0} \boldsymbol{\mu M}$ \\
\hline $\mathbf{1 a}$ & $0.6600 \pm$ & $0.6179 \pm$ & $0.6155 \pm$ & $0.6115 \pm$ & $0.6092 \pm$ & $0.6050 \pm$ & $0.5927 \pm$ \\
& 0.0083 & 0.0398 & 0.0426 & 0.0370 & 0.0376 & 0.0350 & 0.0378 \\
\hline $\mathbf{1 b}$ & $0.5035 \pm$ & $0.4842 \pm$ & $0.4611 \pm$ & $0.4510 \pm$ & $0.4001 \pm$ & $0.3834 \pm$ & $0.3435 \pm$ \\
& 0.0073 & 0.0022 & 0.0153 & 0.0132 & 0.0165 & 0.0123 & 0.0163 \\
\hline $\mathbf{1 c}$ & $0.4752 \pm$ & $0.4134 \pm$ & $0.3943 \pm$ & $0.3745 \pm$ & $0.2902 \pm$ & $0.2252 \pm$ & $0.2083 \pm$ \\
& 0.0053 & 0.0132 & 0.0051 & 0.0060 & 0.0019 & 0.0079 & 0.0078 \\
\hline $\mathbf{2 a}$ & $0.5326 \pm$ & $0.5318 \pm$ & $0.5246 \pm$ & $0.5202 \pm$ & $0.5138 \pm$ & $0.5086 \pm$ & $0.4856 \pm$ \\
& 0.0026 & 0.0018 & 0.0079 & 0.0125 & 0.0037 & 0.0014 & 0.0024 \\
\hline $\mathbf{2 b}$ & $0.566 \pm$ & $0.5582 \pm$ & $0.5562 \pm$ & $0.5452 \pm$ & $0.5058 \pm$ & $0.4685 \pm$ & $0.4096 \pm$ \\
& 0.01202 & 0.0045 & 0.0031 & 0.0005 & 0.0019 & 0.0026 & 0.0121 \\
\hline $\mathbf{2 c}$ & $0.5664 \pm$ & $0.5526 \pm$ & $0.5444 \pm$ & $0.5407 \pm$ & $0.5129 \pm$ & $0.4671 \pm$ & $0.4173 \pm$ \\
& 0.0106 & 0.0088 & 0.0080 & 0.0052 & 0.0025 & 0.0072 & 0.0144 \\
\hline
\end{tabular}

Results are presented as mean \pm SD $(n=3)$

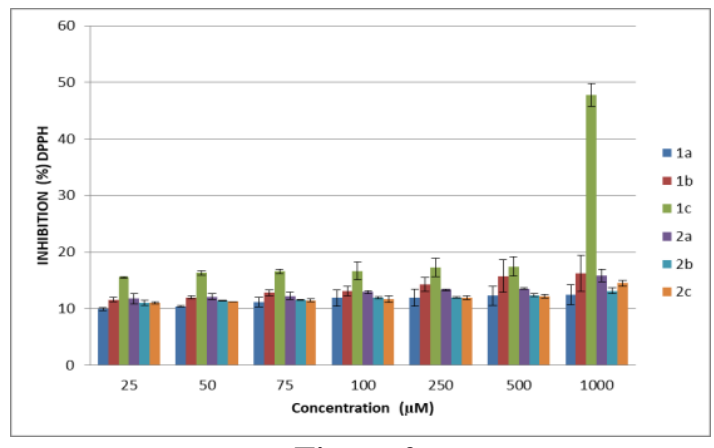

Figure 2.

DPPH free radical scavenger activity (inhibition \%) of analysed compounds

ANOVA test didn't reveal significant differences among analysed compounds (1a, 1c, 2a, 2c) (p = $0.6640>0.05)$.

Scavenger activity towards $A B T S^{\circ+}$ free radical The $\mathrm{ABTS}^{*+}$ free radical results from the reaction between 2,2'-azinobis-(3-ethylbenzothiazoline-6sulfonic acid) diammonium salt and manganese (II) oxide [19], sodium/potassium persulfate [24], 2,2'-

azobis(2-amidinopropane) dihydrochloride [17] or enzymes (peroxidase) [23]. Regarding the $\mathrm{ABTS}^{\circ+}$ assay, the bluish - green radical cation is reduced in the presence of antioxidants (both lipophilic and hydrophilic compounds) [11, 23].

Results regarding the antioxidant activity are presented in Table III and Table IV, and Figure 3. Our results pointed out that the scavenger activity towards $\mathrm{ABTS}^{++}$ free radical increased with concentration for all analysed compounds.

Table II

Ascorbic acid equivalents - DPPH assay

\begin{tabular}{|c|c|}
\hline Compound & $\begin{array}{c}\text { Ascorbic acid equivalents } \\
\text { (mM ascorbic acid/g substance) }\end{array}$ \\
\hline 1a & $0.7609 \pm 0.6415$ \\
\hline $\mathbf{1 b}$ & $\mathrm{nd}$ \\
\hline $\mathbf{1 c}$ & $1.3593 \pm 1.4007$ \\
\hline $\mathbf{2 a}$ & $1.7568 \pm 1.826$ \\
\hline $\mathbf{2 b}$ & $\mathrm{nd}$ \\
\hline $\mathbf{2 c}$ & $1.4260 \pm 9.9823$ \\
\hline
\end{tabular}

n.d. = non-detected

Results are presented as mean \pm SD $(n=3)$

Table III

Absorbance values of $\mathrm{ABTS}^{\circ+}$ solution in the presence of tested compounds

\begin{tabular}{|c|c|c|c|c|c|c|c|}
\hline \multirow{2}{*}{ Compound } & \multicolumn{7}{|c|}{ Concentration $(\boldsymbol{\mu M})$} \\
\cline { 2 - 8 } & $\mathbf{2 5} \boldsymbol{\mu M}$ & $\mathbf{5 0} \boldsymbol{\mu M}$ & $\mathbf{7 5} \boldsymbol{\mu M}$ & $\mathbf{1 0 0} \boldsymbol{\mu M}$ & $\mathbf{2 5 0} \boldsymbol{\mu M}$ & $\mathbf{5 0 0} \boldsymbol{\mu M}$ & $\mathbf{1 0 0 0} \boldsymbol{\mu M}$ \\
\hline $\mathbf{1 a}$ & $0.66 \pm$ & $0.6179 \pm$ & $0.6155 \pm$ & $0.6115 \pm$ & $0.6092 \pm$ & $0.6050 \pm$ & $0.5927 \pm$ \\
& 0.0083 & 0.0398 & 0.0426 & 0.0370 & 0.0376 & 0.0350 & 0.0378 \\
\hline $\mathbf{1 b}$ & $0.5035 \pm$ & $0.4842 \pm$ & $0.4611 \pm$ & $0.4580 \pm$ & $0.4001 \pm$ & $0.3834 \pm$ & $0.3435 \pm$ \\
& 0.0073 & 0.0022 & 0.0153 & 0.0132 & 0.0165 & 0.0123 & 0.0163 \\
\hline $\mathbf{1 c}$ & $0.4752 \pm$ & $0.4134 \pm$ & $0.3943 \pm$ & $0.3745 \pm$ & $0.2902 \pm$ & $0.2252 \pm$ & $0.2083 \pm$ \\
& 0.0053 & 0.0132 & 0.0051 & 0.0060 & 0.0019 & 0.0079 & 0.0078 \\
\hline $\mathbf{2 a}$ & $0.5326 \pm$ & $0.5318 \pm$ & $0.5246 \pm$ & $0.5202 \pm$ & $0.5138 \pm$ & $0.5086 \pm$ & $0.4856 \pm$ \\
& 0.0026 & 0.0018 & 0.0079 & 0.0125 & 0.0037 & 0.0014 & 0.0024 \\
\hline $\mathbf{2 b}$ & $0.5605 \pm$ & $0.5582 \pm$ & $0.5562 \pm$ & $0.5452 \pm$ & $0.5058 \pm$ & $0.4685 \pm$ & $0.4096 \pm$ \\
& 0.0101 & 0.0045 & 0.0031 & 0.0056 & 0.0019 & 0.0026 & 0.0121 \\
\hline $\mathbf{2 c}$ & $0.566 \pm$ & $0.5526 \pm$ & $0.5444 \pm$ & $0.5407 \pm$ & $0.5129 \pm$ & $0.4671 \pm$ & $0.4173 \pm$ \\
& 0.0106 & 0.0088 & 0.0080 & 0.0052 & 0.0025 & 0.0072 & 0.0144 \\
\hline
\end{tabular}

Results are presented as mean \pm SD $(n=3)$

The scavenger activity varied between $2.13 \%$ (for $\mathbf{1 a}-25 \mu \mathrm{M}$ ) and $69.83 \%$ (for 1c - $1000 \mu \mathrm{M}$ ) (Figure 3).
The highest scavenger capacity was observed for compound $\mathbf{1 c}$, followed by compounds $\mathbf{1 b}$ and $\mathbf{2 b}$. 
Compound 1a showed the lowest scavenger activity, as previously observed (DPPH assay).

According to our results, the scavenger activity towards $\mathrm{ABTS}^{\circ+}$ free radical was higher compared to the DPPH assay. Therefore, we assume that the structural differences between carbazol derivatives have a major impact upon their antioxidant potential. Regarding ascorbic acid equivalents, the antioxidant activity increased as follows: $\mathbf{1 a}<\mathbf{2 b}<\mathbf{2 a}<\mathbf{2 c}<$ 1b $<$ 1c (Table IV).

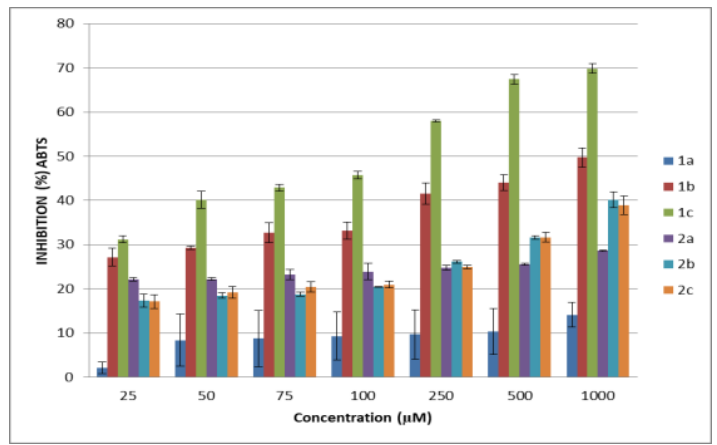

Figure 3.

$\mathrm{ABTS}^{\circ+}$ scavenger activity (inhibition \%) of analysed compounds

Table IV

Ascorbic acid equivalents - ABTS $^{\circ+}$ assay

\begin{tabular}{|c|c|}
\hline Compound & $\begin{array}{c}\text { Ascorbic acid equivalents } \\
\text { (mM ascorbic acid/g substance) }\end{array}$ \\
\hline 1a & $0.4778 \pm 0.4102$ \\
\hline 1b & $5.1100 \pm 4.5307$ \\
\hline 1c & $6.2838 \pm 5.0393$ \\
\hline 2a & $3.3145 \pm 2.5135$ \\
\hline 2b & $3.0826 \pm 2.7378$ \\
\hline 2c & $4.6844 \pm 4.0188$ \\
\hline
\end{tabular}

Results are presented as mean \pm SD $(n=3)$

Our results did not shown significant differences among analysed compounds $(\mathrm{p}=0.2020>0.05)$. The Pearson coefficient (-0.0625) showed a negative, still insignificant correlation between the antioxidant methods $(\mathrm{p}=0.7565)$.

In vivo Artemia franciscana cytotoxic capacity

The cytotoxicity of new compounds can be tested in vivo, by using different organisms and methods, from which we have chosen Artemia franciscana nauplii lethality bioassay. This method can be used for experiments and applications in ecotoxicity, but also in pharmaco-toxicological screening, to evaluate the effects of chemical, new derivatives or natural compounds, on live organisms. Besides, the method has the advantage of being accessible, inexpensive and rapid [1].

The in vivo evaluation of toxicity using Artemia franciscana nauplii lethality bioassay was performed on four of the listed compounds, more specifically on derivatives $\mathbf{1 a}, \mathbf{2 a}, \mathbf{2 b}$ and $\mathbf{2 c}$. Among the four tested derivatives, three (1a, 2a and $\mathbf{2 b})$ didn't show any toxicity at the evaluated concentrations, at the solubility limit, in suspension. After 24 hours, all nauplii were alive and were having normal movements. In the case of substance $\mathbf{2 c}$, a slight toxicity was observed at the maximum concentration evaluated $(100 \mu \mathrm{g} / \mathrm{mL})$, as evidenced by a lethality of $16.67 \%$ ( $10 \%$ in one of the three replicas and $20 \%$ in the other two replicas). The data were insufficient to allow the computation of $\mathrm{IC}_{50}$ (possible only by extrapolation), but it may be concluded that this substance has a slightly higher toxicity than the other three, for which no case of toxicity or lethality was registered.

In the scientific literature, it has been suggested that an $\mathrm{IC}_{50}$ value ranging between 30 and $100 \mu \mathrm{g} / \mathrm{mL}$ for the Artemia sp. toxicity corresponds to a modest, weak toxicity $[13,21]$. The other evaluated compounds didn't show any toxicity at concentrations up to 100 $\mu \mathrm{g} / \mathrm{mL}$, and thus their toxicity may be considered modest. Still it must be taken into consideration that the solubility limitations did not allow an assessment of toxicity in solution.

\section{Conclusions}

The analysed compounds have shown in vitro scavenger activities towards DPPH and $\mathrm{ABTS}^{\circ+}$ free radicals. The highest antioxidant activity was observed for compounds 1c and 1b. By means of $\mathrm{ABTS}^{\text {+t }}$ assay, promising results were also observed for compound 2b. Regarding Artemia franciscana nauplii lethality bioassay, the results indicate a low level of toxicity for the analysed compounds. Further studies are necessary to confirm the in vivo antioxidant capacity of the tested compounds and moreover their safety in pre-clinical studies.

\section{Conflict of interest}

The authors declare no conflict of interest.

\section{References}

1. Artoxkit M, Artemia Toxicity Screening Test for Estuarine and Marine Waters. Standard Operational Procedure. Microbiotests, Mariakerke-Gent, 2014.

2. Bashir M, Bano A, Ijaz SA, Chudhary BA, Recent development and biological activity of $\mathrm{N}$-substituted carbazole derivatives: a review. Molecules, 2015; 20: 13496-13517.

3. Bharatiya N, Gharu CP, Green and efficient microwave one-pot synthetic approach to $\mathrm{N}$-phenyl piperazinyl-1,3,4-oxadiazole derivatives and evaluation of their antioxidant and anti-inflammatory activity. Ind J Appl Res., 2014; 4: 88-90.

4. Bordei (Telehoiu) AT, Nuță DC, Căproiu MT, Dumitraşcu F, Zarafu I, Ioniță P, Bădiceanu CD, Avram S, Chifiriuc MC, Bleotu C, Limban C, Design, synthesis and in vitro characterization of novel antimicrobial agents based on 6-chloro-9H-carbazol 
derivatives and 1,3,4-oxadiazole scaffolds. Molecules, 2020; 25(2): 266: 1-18.

5. Brand- Williams W, Cuvelier ME, Berset C, Use of a free radical method to evaluate antioxidant activity. LWT-Food Sci Technil., 1995; 28(1): 25-30.

6. Cock IE, Kalt FR, Toxicity evaluation of Xanthorrhoea johnsonii leaf methanolic extract using the Artemia franciscana bioassay. Pharmacogn. Mag., 2010, 6(23): 166-171.

7. Cock IE, Van Vuuren SF, A comparison of the antimicrobial activity and toxicity of six Combretum and two Terminalia species from southern Africa. Pharmacogn Mag., 2015; 11(41): 208-218.

8. Costea T, Bădiceanu CD, Nuță DC, Gîrd CE, Limban C, Karampelas O, Avram S., Antioxidant activity and drug profile of several thiourea derivatives of 2-thiophene carboxylic acid Farmacia, 2020; 68(6): 1047-1054.

9. Costea T, Lupu A-R, Vlase L, Nencu I, Gîrd CE, Phenolic content and antioxidant activity of a raspberry leaf dry extract. Rom Biotechnol Lett., 2016; 21(2): 11345-11356.

10. Deepshikha G, Methods for determination of antioxidant capacity: a review. Int J Pharm Sci Res., 2015; 6(2): 546-566.

11. Dudonné S, Vitrac X, Coutierré P, Woillez M, Mérillon JM, Comparative study of antioxidant properties and total phenolic content of 30 plant extracts of industrial interest using DPPH, ABTS, FRAP, SOD and ORAC assays. J Agric Food Chem., 2009; 57(5): 1764-1778.

12. Germanò MP, Cacciola F, Donato P, Dugo P, Certo G, D'Angelo V, Mondello L, Rapisarda A, Betula pendula leaves: polyphenolic characterization and potential innovative use in skin whitening products. Fitoterapia, 2012; 83(5): 877-882.

13. Hamidi MR, Jovanova B, Panovska TK, Toxicological evaluation of the plant products using Brine Shrimp (Artemia salina L.) model. Maced Pharm Bull., 2014; 60(1): 9-18.

14. Knölker HJ, Reddy KR, Isolation and synthesis of biologically active carbazole alkaloids. Chem Rev., 2002; 102(11): 4303-4428.

15. Landis JT, An H, Bailey AG, Dittmer DP, Marron JS, Dose Response Data Analysis using the 4 Parameter Logistic (4pl) Model, https://CRAN.R-project.org/ package $=\mathrm{dr} 4 \mathrm{pl}$.

16. Lobo AP, García-Diñeiro Y, Mangas-Sanchez J, Madrera-Rodríguez R, Valles-Suárez B, Phenolic and antioxidant composition of cider. J Food Compost Anal., 2009; 22(7-8): 644-648.

17. Magalhäes LM, Segundo MA, Reis S, Lima JLFC, Methodological aspects about in vitro evaluation of antioxidant properties. Anal Chem Acta, 2008; 613(1): $1-19$.

18. Meyer BN, Ferrigni NR, Putnam JE, Jacobsen LB, Nichols DE, McLaughlin JL. Brine shrimp: a convenient general bioassay for active plant constituents. Planta Med., 1982, 45(5): 31-34.

19. Miller JN, Sampson J, Candeias LP, BramLey PM, Rice-Evans CA, Antioxidant activities of carotens and xantophylls. FEBS Letters, 1996; 384(3): 240242.

20. Molyneux P, The use of the stable free radical diphenylpicryl-hydrazyl (DPPH) for estimating antioxidant activity. Songklanakarin J Sci Technol., 2004; 26(2): 212-219.

21. Moshi MJ, Innocent E, Magadula JJ, Otieno DF, Weisheit A, Mbabazi PK, Nondo RSO. Brine shrimp toxicity of some plants used as traditional medicines in Kagera Region, north western Tanzania. Tanzan $J$ Health Res., 2010; 12(1): 63-67.

22. Ohnishi M, Morishita H, Toda S, Shirataki Y, Kimura $\mathrm{M}$, Inhibitory effects of chlorogenic acids on linoleic acid peroxidation and haemolysis. Phytochemistry, 1994; 36(3): 579-583.

23. Prior RL, Wu X, Schaich K, Standardized methods for the determination of antioxidant capacity and phenolics in food and dietary supplements. J Agric Food Chem., 2005; 53: 4290-4302.

24. Re R, Pellegrini N, Proteggente A, Pannala A, Yang M, Rice-Evans C, Antioxidant activity applying an improved ABTS radical cation decolorization assay. Free Radic Biol Med., 1999; 26(9-10): 1231-1237.

25. Sam TW, Toxicity testing using the brine shrimp Artemia salina. In: Bioactive natural products detection, isolation, and structural determination. CRC Press, Boca Raton (FL), 1993, 441-456.

26. Sehwag S, Das M, Antioxidant activity: an overview. J Food Sci Technol., 2013; 2(3): 1-11.

27. Sharma OP, Bhat TK, DPPH antioxidant assay revisited. Food Chem., 2009; 113(4): 1202-1205.

28. Tuță-Sas I, Proks M, Păunescu V, Pînzaru I, Sas I, Coricovac D, Moacă A, Dehelean C, Thymus vulgaris extract formulated as cyclodextrin complexes: synthesis, characterization, antioxidant activity and in vitro cytotoxicity assessment. Farmacia, 2019; 67(3): 442-451.

29. Thaipong K, Boonprakob U, Crosby K, CisnerosZevallos L, Byrne DH, Comparison of ABTS, DPPH, FRAP and ORAC assays for estimating activity from guava fruits. J Food Compost Anal., 2006; 19 (6-7): 669-675.

30. Yuan YV, Bone DE, Carrington MF, Antioxidant activity of dulse (Palmaria palmata) extract evaluated in vitro. Food Chem., 2005; 91(3): 485-494. 